\title{
Impact of Microbiological Fertilizer Baikal EM-1 on Onion Growth in Greenhouse Conditions
}

\author{
Lelde Grantina-Ievina, Lasma Stanke, Guna Ergle \\ Latvian Plant Protection Research Centre, \\ Struktoru 14A, Riga, LV-1039, Latvia; E-mail: lelde.grantina-ievina@laapc.lv
}

\begin{abstract}
The microbiological fertilizer Baikal EM-1 contains lactic acid bacteria, photosynthetic bacteria, nitrogen fixing bacteria, Saccharomyces yeasts and microbial cultivation media. The aim of the present study was to evaluate the impact of it on onion grown in controlled greenhouse conditions.

In summer 2014 two trials with this product were carried out on onions in greenhouse conditions. Before planting onion bulbs were soaked in water with added fertilizer and growth substrate was watered with the fertilizer according to the instructions of manufacturer. During the vegetation period plants were watered with the fertilizer several times. Identical treatment was performed with water in the control plots. Different treatment schemes and growth substrates (neutralized peat and substrate for vegetables) were used in both trials. The main difference of the used substrates was in the content of mineral nutrients that was higher in the substrate for vegetables. In the second trial additional fertilization with ammonium nitrate was applied three times during the vegetation period. At the end of the trials the yield of onion leaves was estimated, as well as the length of leaves and their chlorophyll content was measured.

At the first trial the obtained yield of onion leaves was increased by $6.4 \%$ and in the second by $8.2 \%$ due to treatment with Baikal EM-1 but these differences were not statistically significant in comparison to the control plots. In general, the fertilizer increased all other measured parameters as well, including average length of leaves by $4.6 \%$ and $1.3 \%$, the chlorophyll content by $5.0 \%$ and $1.5 \%$, in the first and second trial respectively, and percentage of onions developing leaves increased by $13.2 \%$ in the second trial. Only the last parameter showed statistically significant differences in comparison to the control. Additionally the growth of the onion was more even in the control treatment. In conclusion, the microbiological fertilizer Baikal EM-1 gave positive impact on onions in greenhouse conditions.
\end{abstract}

Keywords: chlorophyll content, microbiological fertilizer, onions, yield.

\section{INTRODUCTION}

Microorganisms and their populations in soil and rhizosphere are important players for plant nutrition and health. Beneficial soil microorganisms are responsible for soil born disease suppressiveness [1]. Various soils contain diverse microbial populations. The most important for nitrogen nutrition are nitrogen fixing bacteria, nitrifiers and denitrifiers [2].

Several studies have shown positive impact of the microbiological fertilizer Baikal EM-1on plants. This fertilizer contains among nitrogen fixing bacteria also lactic acid bacteria, photosynthetic bacteria, Saccharomyces yeasts and microbial cultivation media. Lactic acid bacteria have been isolated from rhizosphere of fruit trees [3]. Application of photosynthetic bacteria has increased grain yield of rice plants [4] and has shown potential for biocomposting [5]. Baikal EM-1, containing broad spectrum of microorganisms, has reduced the inhibition of photosystem II activity of tree seedlings in the conditions of salt stress [6]. In field conditions Baikal EM-1 (1 and $2 \%$ ) has increased yield of maize by 1.85 and $2.65 \mathrm{t} \mathrm{h}^{-1}$, respectively, chlorophyll content in leaves of maize [7] and yield of sugarbeet [8]. A bio-fertilizer, containing Lactobacillus casei, Lactobacillus lactis, Rhodopseudomonas palustris, Saccharomyces cerevisiae, has improved yield of tomato in greenhouse conditions by 13 and $19 \%$ if used in soil or foliar application [9]. Since scientific information about the microbiological fertilizer Baikal EM-1 is limited, the aim of the present study was to evaluate the impact of it on onion grown in controlled greenhouse conditions.

\section{MATERIALS AND METHODS}

In summer 2014 two trials with Baikal EM-1 (EM Technology, Russia) were conducted on onion (Allium cepa L.), cultivar 'Stuttgarter Riesen' (distributed by Latvijas Skirnes Seklas Ltd, Latvia) in greenhouse conditions in Kekava region (Latvia). 
Before planting onion bulbs were soaked in water with the added fertilizer $(0.1 \%)$ and growth substrate was treated with the fertilizer $(1 \%)$ according to the instructions of the manufacturer. During the vegetation period plants were watered with the fertilizer several times. Identical treatment was performed with water in the control plots. Different treatment schemes and growth substrates (neutralized peat and substrate for vegetables) were used in the trials (Table 1). The main difference of the used substrates was in the content of phosphorus that was two times higher in the substrate for vegetables. In the second trial additional fertilization was performed three times during the vegetation period with ammonium nitrate (Agrochema Latvia Ltd, content: total nitrogen $34.4 \%$; ammonium $\mathrm{N}^{-\mathrm{NH}_{4}} 17.2 \%$; nitrates $\mathrm{N}-\mathrm{NO}_{3} 17.2 \%$ ) and malt extract was added to the fertilizer solution as suggested by the Baikal EM-1 manufacturer in order to activate the microorganisms present in the preparation. The trials were carried out in greenhouse conditions, and onions were planted in eight plastic boxes per treatment. Boxes were regularly watered manually.

In the first trial all onions were able to develop leaves but in the second trial the sprouting capacity was reduced and therefore the number of onions developing leaves was counted at the end of the trial.

At every treatment and assessment, the average air temperature and air humidity in the greenhouse was measured.

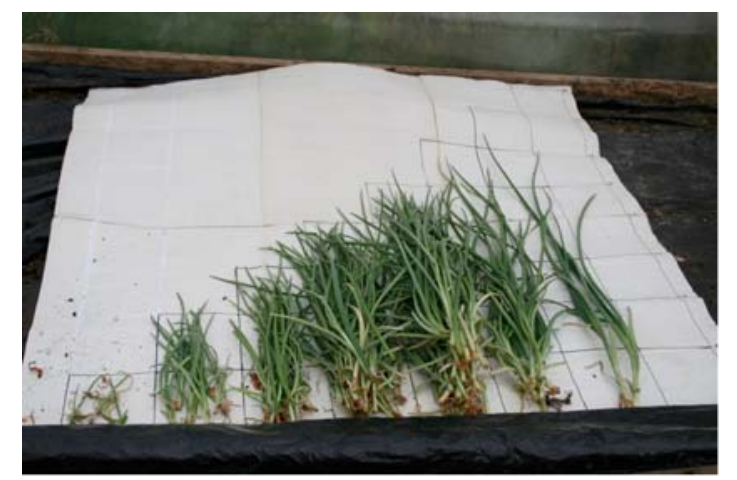

Fig. 1. Sorting of onion in groups depending from the length of the leaves in the second trial.

At the end of the trials, at four- to five-leaf stage, the yield of onion leaves per box was estimated (fresh weight), as well as the average length of leaves and their chlorophyll content was measured (five measurements per box) using a hand-held chlorophyll meter SPAD-502 (Konica-Minolta, Japan). At the end of the second trial all onions from each box were sorted in groups depending from the length of the leaves (Fig. 1) and respective number of onion and weight of each group $(0-10 \mathrm{~cm}, 11-20 \mathrm{~cm}, 21-30 \mathrm{~cm}$, $31-40 \mathrm{~cm}, 41-50 \mathrm{~cm}, 51-60 \mathrm{~cm}, 61-70 \mathrm{~cm})$ was estimated.

Significance of differences between means was determined by the t-test at the $\alpha=0.05$ level with Excel (Microsoft, USA). Significance was evaluated at $p<0.05$ level.

TABLE I

TREATMENT SCHEMES

\begin{tabular}{|c|c|c|}
\hline Process & First trial & Second trial \\
\hline Size of plastic boxes, $\mathrm{m}^{2}$ & 0.24 & 0.10 \\
\hline $\begin{array}{l}\text { Substrate treatment two weeks before planting } \\
\text { with } 1 \% \text { Baikal EM-1 solution }\end{array}$ & yes & no \\
\hline $\begin{array}{l}\text { Soaking of onion bulbs before planting in } 0.1 \\
\text { \% Baikal EM-1 solution }\end{array}$ & $20 \mathrm{~min}$ & $12 \mathrm{~h}$ \\
\hline Planting, $1500 / \mathrm{m}^{2}$ & 07.05 .2014 & 25.07 .2014 \\
\hline Spraying with $0.001 \%$ Baikal EM-1 solution & one time & none \\
\hline Watering with $0.001 \%$ Baikal EM-1 solution & two times & three times \\
\hline $\begin{array}{l}\text { Addition of malt extract }(0.001 \%) \text { to Baikal } \\
\text { EM-1 solution }\end{array}$ & no & in all treatments \\
\hline Fertilizing with ammonium nitrate, $10 \mathrm{~g} \mathrm{~m}^{-2}$ & no & three times with $7-8$ day interval \\
\hline Harvest & 02.06 .2014 & 28.08 .2014 \\
\hline Substrate and its content & $\begin{array}{l}\text { Neutralized peat „Kasvuturvas”, Estonian } \\
\text { Peat Products Ltd., Estonia } \\
\text { Added nutrients, g mg } 1^{-1} \text { : } \\
\text { Nitrogen }\left(\mathrm{NH}_{4} \text { and } \mathrm{NO}_{3}\right)-120.00 \\
\text { Phosphorus }\left(\mathrm{P}_{2} \mathrm{O}_{3}\right) 140.00 \\
\text { Potassium }-\left(\mathrm{K}_{2} \mathrm{O}\right) 240.00 \\
\end{array}$ & $\begin{array}{l}\text { Substrate for vegetables „Terra Vita”, SAS } \\
\text { "MNPP PHART”, Russia. } \\
\text { Content, } \mathrm{mg} \mathrm{l}^{-1} \text { : } \\
\text { Nitrogen }\left(\mathrm{NH}_{4} \text { and } \mathrm{NO}_{3}\right) 150.00 \\
\text { Phosphorus }\left(\mathrm{P}_{2} \mathrm{O}_{5}\right) 270.00 \\
\text { Potassium }\left(\mathrm{K}_{2} \mathrm{O}\right) 300.00 \text {. }\end{array}$ \\
\hline
\end{tabular}

\section{RESULTS AND DISCUSSION}

In the first trial the average length of onion leaves at the harvest in the control was $34.94 \pm 3.25 \mathrm{~cm}$. The average length of onion leaves in the treatment was
$36.55 \pm 2.09 \mathrm{~cm}$. The difference was $4.61 \%$ but it was statistically not significant $\left(t_{\text {Stat }}=1.17<t_{\text {Critical two-tail }}=\right.$ $2.15)$. At the first trial the obtained yield of onion leaves per box of the control was $585 \pm 67.40 \mathrm{~g}$ that corresponds to $24.4 \mathrm{tha}^{-1}$. The obtained onion yield in 
the treatment was $622.5 \pm 83.79 \mathrm{~g}$ per box $\left(0.24 \mathrm{~m}^{2}\right)$ that corresponds to $25.9 \mathrm{t} \mathrm{ha}^{-1}$. The difference was $6.41 \%$ but it was statistically not significant $\left(t_{\text {Stat }}=\right.$ $\left.0.99<t_{\text {Critical two-tail }}=2.15\right)$. The average chlorophyll content of onion leaves in the control was $17.08 \pm$ 1.61 SPAD units. The average chlorophyll content of onion leaves in the treatment was $17.92 \pm 1.82$ SPAD units that was increased by $4.92 \%$ in comparison to the control. This difference was statistically not significant $\left(t_{\text {Stat }}=0.97 t_{\text {Critical two-tail }}=2.15\right)$.

In the first trial all onions were able to develop leaves but in the second trial only $70.83 \pm 12.36 \%$ of bulbs developed leaves in the control but $84.00 \pm 2.89$ $\%$ bulbs developed leaves in the treatment. The difference was $13.17 \%$ and it was statistically significant $\left(p=0.02 ; t_{\text {Stat }}=2.93>t_{\text {Critical two-tail }}=2.31\right)$.

In the first trial at the harvest the average length of the onion leaves in the control was $40.88 \pm 3.70 \mathrm{~cm}$. The average length of the onion leaves in the treatment was $41.41 \pm 3.91 \mathrm{~cm}$. The difference was $1.31 \%$ but it was statistically not significant $\left(t_{\text {Stat }}=\right.$ $0.28<t_{\text {Critical two-tail }}=2.15$ ).

At the second trial the obtained yield of onion leaves per box of the control was $438.13 \pm 44.60 \mathrm{~g}$ that corresponds to $43.8 \mathrm{t} \mathrm{ha}^{-1}$. The obtained onion yield in the treatment was $474.00 \pm 33.81 \mathrm{~g}$ per box $\left(0.1 \mathrm{~m}^{2}\right)$ that corresponds to $47.4 \mathrm{t} \mathrm{ha}^{-1}$. The difference was $8.19 \%$ but it was statistically not significant $\left(t_{\text {Stat }}=1.81<t_{\text {Critical two-tail }}=2.15\right)$.

The average chlorophyll content of onion leaves in the control was $25.80 \pm 0.91$ SPAD units. The average chlorophyll content of onion leaves in the treatment was $26.18 \pm 1.18$ SPAD units. The difference was $1.47 \%$ but it was statistically not significant $\left(t_{\text {Stat }}=\right.$ $0.32<t_{\text {Critical two-tail }}=2.15$ ).

The average chlorophyll content was statistically significantly higher in the second trial in the control $\left(p<0.001 ; t_{\text {Stat }}=8.65>t_{\text {Critical two-tail }}=2.15\right)$ as well as in the treatment $\left(p<0.001 ; t_{\text {Stat }}=7.77>t_{\text {Critical two-tail }}=\right.$ 2.15) in comparison to the first trial. Differences between trials can be explained by the higher level of nitrogen in the substrate used for the second trial and additional fertilization with ammonium nitrate. However the detected level of the chlorophyll has to be considered low in comparison to other investigations were onion has been grown on organic soils and the chlorophyll content was estimated with the same method. For example, in the study of Westerveld et al. [9] the chlorophyll content of yellow cooking onion cultivar 'Hamlet' leaves at five-leaf stage varied from 46.9 to 56.2 SPAD units on organic soil in field conditions depending from the amount of nitrogen rate in the fertilization $\left(0-200 \mathrm{~kg} \mathrm{ha}^{-1}\right)$ and year of the trial. Such differences can be explained by different growth conditions (greenhouse vs. field) and different cultivars.

The average yield of fresh onion leaves was statistically significantly higher in the second trial in the control $\left(p<0.001 ; t_{\text {Stat }}=2.76>t_{\text {Critical two-tail }}=\right.$
$2.15)$ as well as in the treatment $\left(p<0.001 ; t_{\text {Stat }}=2.79\right.$ $\left.>t_{\text {Critical two-tail }}=2.15\right)$ in comparison to the first trial. This can be explained by a higher amount of mineral nutrients in the substrate used in the second trial. Increased fresh weight of onion leaves followed by higher potassium and phosphorus concentrations, for example, has been reported in other investigations as well $[11,12]$.

Sorting of onion in groups depending from the length of the leaves has shown that in the treatment higher biomass was obtained in the length groups up to $50 \mathrm{~cm}$, especially in the length group $31-40 \mathrm{~cm}$ (Table 2) where this difference was statistically significant in comparison to the control $(p=0.01$, $\left.t_{\text {Stat }}=3.00>t_{\text {Critical two-tail }}=2.15\right)$. In the length groups $51-60 \mathrm{~cm}$ and $61-70 \mathrm{~cm}$ the highest biomass was observed in the control, especially in the length group $51-60 \mathrm{~cm}$, where the difference in comparison to treatment was statistically significant $\left(p=0.01, t_{\text {Stat }}=\right.$ $2.78>t_{\text {Critical two-tail }}=2.15$ ).

Number of onion in the control boxes was higher in the smallest $(0-20 \mathrm{~cm})$ and largest length groups $(51-70 \mathrm{~cm})$ but in the treatment number of onion was higher in the length categories from 21 to $50 \mathrm{~cm}$ (Table 2) that is more suitable for the production quality.

Plant growth-promoting soil microorganisms improve plant nutrition and growth characteristics through various processes including nitrogen fixation, breakdown of organic substances, solubilization of minerals, release of chelating compounds and biologically active molecules such as phytohormones, vitamins and enzymes, and, as a result, improve the nutrient uptake by plant root system [13]. In the present study the tested fertilizer significantly increased the sprouting capacity of onion, slightly increased the length of the onion leaves, the fresh weight, the chlorophyll content, and the growth evenness. The growth period of the onion was remarkably shorter than in other studies where crops with longer vegetation period were used, such as tree seedlings, maize, sugarbeet and tomatoes $[6,7,8,9]$. Probably the time period in the present study was too short for the beneficial microorganisms of the fertilizer Baikal EM-1 to multiply up to effective level and to give the maximal potential.

\section{CONCLUSIONS}

Although the level of mineral nutrients caused significant impact on the yield of onion leaves (fresh weight), as well as the average length of leaves and their chlorophyll content, the added fertilizer has shown positive impact of these parameters if comparing the control plots with treatment plots. Additionally Baikal EM-1 showed plant growth stimulating activity in the second trial when the sprouting capacity of onions was reduced. The percentage of onions developing leaves was increased 
by $13.2 \%$ in comparison to the control plots, and the suitable for the production quality aspects. length of the onion leaves was more even that is

TABLE 2

ONION FRESH MASS AND NUMBER OF PLANTS IN EVERY LENGTH GROUP

\begin{tabular}{|l|c|c|c|c|c|c|c|}
\hline Measured parameter & $0-10 \mathrm{~cm}$ & $11-20 \mathrm{~cm}$ & $21-30 \mathrm{~cm}$ & $31-40 \mathrm{~cm}$ & $41-50 \mathrm{~cm}$ & $51-60 \mathrm{~cm}$ & $61-70 \mathrm{~cm}$ \\
\hline $\begin{array}{l}\text { Fresh mass (g) ( } \pm \text { S.D.) } \\
\text { in the control }\end{array}$ & $0.75 \pm 0.46$ & $6.13 \pm 2.47$ & $20.75 \pm 5.18$ & $91.75 \pm 33.38$ & $196.75 \pm 30.87$ & $109.63 \pm 29.26$ & $12.38 \pm 15.95$ \\
\hline $\begin{array}{l}\text { Fresh mass (g) ( } \pm \text { S.D.) } \\
\text { in the treatment }\end{array}$ & $0.88 \pm 0.35$ & $6.38 \pm 3.46$ & $26.75 \pm 9.97$ & $141.50 \pm 32.91$ & $225.75 \pm 56.70$ & $67.38 \pm 31.37$ & $5.38 \pm 11.70$ \\
\hline $\begin{array}{l}\text { Number of plants ( } \\
\text { S.D.) in the control }\end{array}$ & $2.38 \pm 2.07$ & $7.00 \pm 2.45$ & $13.63 \pm 3.02$ & $28.63 \pm 10.50$ & $37.75 \pm 9.38$ & $14.13 \pm 3.40$ & $1.25 \pm 1.58$ \\
\hline $\begin{array}{l}\text { Number of plants ( } \pm \\
\text { S.D.) in the treatment }\end{array}$ & $2.50 \pm 1.85$ & $6.50 \pm 2.33$ & $16.00 \pm 5.58$ & $42.25 \pm 8.97$ & $44.25 \pm 10.94$ & $9.88 \pm 3.83$ & $0.75 \pm 1.75$ \\
\hline
\end{tabular}

\section{$\mathrm{V}$ ACKNOWLEDGEMENTS}

We are very thankful to EM Technologies for providing the fertilizer used in the study.

\section{REFERENCES}

[1] R. L. Berendsen, C. M. J. Pieterse, P. A. H. M. Bakker, "The rhizosphere microbiome and plant health," Trends Plant Sci., vol. 17, pp. 478- 486, 2012.

[2] T.-H. Anderson, "Microbial eco-physiological indicators to asses soil quality," Agric. Ecosyst. Environ., vol. 98, pp. 285293, 2003.

[3] Y.-S. Chen, F. Yanagida, T. Shinohara, "Isolation and identification of lactic acid bacteria from soil using an enrichment procedure," Lett. Appl. Microbiol., vol. 40, pp. 195200, 2005.

[4] M. Kobayashi, M. Z. Haque, "Contribution to nitrogen fixation and soil fertility by photosynthetic bacteria," Plant Soil, vol. 35, pp. 443-456, 1971.

[5] M. M. Roper, J. K. Ladha, "Biological $\mathrm{N}_{2}$ fixation by heterotrophic and phototrophic bacteria in association with straw," Dev. Plant Soil Sci., vol. 65, pp. 211-224, 1995.

[6] S. Allahverdiyev, A. Atilla, B. S. Ismail, A. Sahmurova, "Response of photosystem II and photosynthetic pigments to salt and Baikal EM1 in tree seedlings," Afr. J. Biotechnol., vol. 10, pp. 535-538, 2011.

[7] Z. P. Okazova, M. V. Efakov, "Use of biological products in corn seed farming," Plant Protect., vol. 40, pp. 261-263, 2014.

[8] A. K. Kulikova, O. S. Dronina, E. A. Nikiforov, "Effect of seed treatment by diatomite powder on soil nutrient status and sugarbeet productivity," Sakharnaya Svekla, vol. 1, pp. 24-26, 2009.

[9] S. M. Westerveld, A. W. McKeown, M. R. McDonald, "Assessment of chlorophyll and nitrate meters as field tissue nitrogen tests for cabbage, onions, and carrots," HortTechnology, vol 14, pp. 179-188, Apr.-June. 2004.

[10] I. Tringovska, "The effects of humic and bio-fertilizers on growth and yield of greenhouse tomatoes," Acta Hort., vol. 960, pp. 443-449, 2012.

[11] A. M. El-Bassiony, "Effect of potassium fertilization on growth, yield and quality of onion plants," J. Appl. Sci. Res., vol. 2, pp. 780-785, 2006.

[12] A. M. Shaheen, M. M. Abdel-Mouty, A. H. Ali, F. A. Rizk, "Natural and chemical phosphorus fertilizers as affected onion plant growth, bulbs yield and its some physical and chemical properties," Austr. J. Basic Appl. Sci., vol. 1, pp. 519-524, 2007.

[13] C. Altomare, I. Tringovska, "Beneficial soil microorganisms, an ecological Aalternative for soil fertility management," Sust. Agric. Rev., vol. 7, pp 161-214, May 2011. 